
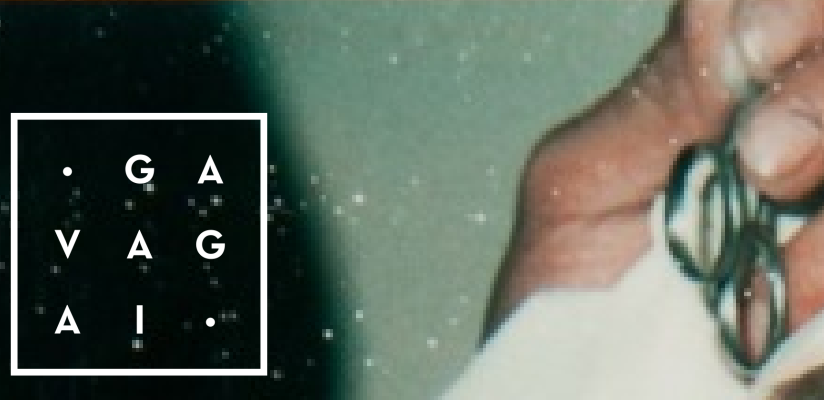

$\because$. 


\section{OS REFLEXOS DO \\ COLONIALISMO EM \\ FICÇÕES \\ ALIENÍGENAS}

LOS REFLEJOS DEL COLONIALISMO EN FICCIONES ALIENÍGENAS

REFLECTIONS OF COLONIALISM IN EXTRATERRESTRIAL FICTIONS

Marcio Markendorf ${ }^{1}$

${ }^{1}$ Professor Adjunto II do Curso de Bacharelado em Cinema na UFSC - Universidade Federal de Santa Catarina. E-mail: marciomarkendorf@gmail.com. 
RESUMO / RESUMEN / ABSTRACT

Resumo: O objetivo deste ensaio é discutir a representação do alienígena na ficção, destacando os conteúdos colonialistas presentes no gênero. Percebido como figura retórica da alteridade, o ser alienígena confundese com a imagem do estranho e do estrangeiro, algo que precisa ser controlado ou destruído para manter a identidade e estabilidade da nação. Por esse viés é que questões diversas - imperialistas, colonialistas, raciais - emergem nos subtextos e nas premissas de obras cinematográficas e de literatura. Mesclando análises conceituais e conjecturas empíricas, o texto apresentado procura demonstrar porque os alienígenas tornamse uma projeção da própria história colonial terrestre, fato que produz um tipo de horror, cujo medo está diretamente ligado a um destino coletivo de colonização - a Terra como uma colônia; os seres humanos como escravos.

Palavras-chave: Colonialismo. Alienígenas. Alteridade. Imaginário.

Resumen: El propósito de este ensayo es discutir la representación del alienígena en la ficción con relieve en los contenidos colonialistas presentes en el género. Visto como figura retórica del otro, el ser alienígena se mezcla con la imagen de lo extraño y del extranjero, algo que necesita ser controlado o destruido para mantener la identidad y estabilidad de la nación. De esa manera es que cuestiones diversas - imperialistas, colonialistas, racial - surgen en los subtextos y en las premisas de obras del cine y la literatura. La fusión del análisis conceptual y conjeturas empíricas, el texto presentado procura demonstrar por qué los alienígenas se convierten en proyección de su propia historia colonial terrestre, hecho que produce un tipo de horror cuyo miedo está conectado directamente a un destino colectivo de la colonización - la Tierra como colonia; los seres humanos como esclavos.

Palabras clave: Colonialismo. Alienígenas. El otro. Imaginario.

Abstract: The aim of this paper is to discuss the representation of the extraterrestrial in fiction highlighting the colonialist's content in this genre. Perceived as rhetorical figure of otherness, the alien (as an extraterrestrial) can be confused with the image of the strange and the foreign, entities that need to be controlled or destroyed by the State in order to keep the identity and the nation's stability. In this context some issues emerge in subtexts and premises of films and literature narratives like the imperialist, the colonialist and the racial themes. Combining conceptual analysis and empirical conjectures, the present essay tries to demonstrate why extraterrestrials became a projection of Earth's colonial history which produces a type of horror whose fear is directly linked to a collective destiny of colonization - the Earth as a colony; humans as slaves.

Keywords: Colonialism. Extraterrestrials. Otherness. Imaginary. 


\section{POR UM ENQUADRAMENTO TEÓRICO DA NARRATIVA ALIENÍGENA}

"Os alienígenas estão entre nós" pode ser considerada uma máxima do mundo contemporâneo, pois, de tanto serem vistos em audiovisuais, propagandas, revistas e livros, tornaram-se figuras recorrentes da fantasia, um tipo de arquétipo da ficção científica e dos filmes de terror. Tudo porque, diante da curiosidade pelo cosmos e inconformado com a condição de ser a única forma viva inteligente no Universo, o ser humano sonha com a possibilidade de ser visitado ou confrontado com entidades extraterrenas. Uma relação que acabou gerando um paradoxo: ao mesmo tempo em que o homem desacredita a solidão galáctica, teme a companhia espacial. A ausência de ou a ignorância quanto à existência de outras formas de vida complexa fora da Terra tende a aprofundar o sentimento de fragilidade, pequenez ou insignificância que sempre rondou a humanidade, indefesa frente ao grande mistério da Criação. Mesmo os cientistas sentem-se incomodados com tal estado singular do planeta Terra depois de um evento da magnitude do Big Bang. Como bem destacou o ficcionista Arthur C. Clarke: "Existem duas possiblidades... ou estamos sós no Universo ou não estamos. Ambas são igualmente aterrorizantes"2.

A confluência dessa incerteza radical, do sentimento de perigo representado pelo desconhecido e do potencial maléfico do que vem do exterior pode ser enquadrada no que H. P. Lovecraft (2008) denomina "horror cósmico" - a atualização de um medo primitivo presente no imaginário coletivo, fruto do enlace entre terror e ciência, expresso por histórias fantásticas acerca da escuridão do espaço sideral. Segundo o autor norte-americano, a forma mais expressiva do medo terá lugar no momento em que a espécie humana, situada em uma escala inferior da Criação, acordar de sua falsa orfandade cósmica e for confrontada com seres superiores, provenientes de orbes alienígenas. À primeira vista, parece ser por essa razão que os aliens são representados em grande parte dessas histórias como uma sociedade progressista, disposta a tomar o planeta e a promover o morticínio da humanidade. Semelhante representação da ameaça, desde os primeiros relatos, está amparada pelo mito-alerta da civilização avançada carente de recursos naturais.

A narrativa trivial do alienígena invasor constrói-se a partir do planeta vitimado pela destruição atômica, ou com recursos naturais à beira do esgotamento, de modo que se desenvolve uma relação muito íntima entre aparatos high-tech, escassez de matéria-prima e necessidade impetuosa de expansão territorial. Partindo dessa hipótese inicial, é possível entrelaçar análises conceituais e conjecturas empíricas sobre o horror cósmico para avaliar a ficção cinematográfica alienígena. O exercício crítico é empírico, porque muitos dos componentes relacionados à alegoria estão representados nas próprias ficções analisadas, na forma de diálogos, ações narrativas ou imagens simbólicas. A estrutura alegórica dessas produções cinematográficas quase sempre está subentendida, de modo que a leitura do filme pelo seu valor de face pode muito bem dar a percebê-lo como uma aventura pelo espaço, uma história de ação interplanetária ou um terror cósmico. Tornar evidentes esses componentes ordenadores de certo tipo de leitura é uma questão empírica.

Com as grandes expedições marítimas, em nível planetário e ainda em tempos de descobrimento dos espaços geográficos, os territórios intocados pelos europeus e descobertos além-mar, cujas florestas são símbolo do Éden terrestre, o que se poderia denominar de Primeira Natureza, representavam o lugar no qual aquela civilização ainda não havia penetrado. Em tempos globais como os de hoje, há um imaginário cósmico, situado em um nível interplanetário, que transforma os planetas distantes na imagem do paraíso intocado pela civilização humana, uma Segunda Natureza. Por essa razão, o espaço sideral passou a ser explorado mais sistematicamente por narrativas quando as descobertas do território terrestre - desertos, florestas, continentes, bem como mares e ilhas -, deixaram de ser marcadas pelo exótico e/ou pelo intocado.

De acordo com a perspectiva de Victor Segalen (1989), a partir do momento que se descobriu que a Terra era uma esfera, distanciarse de um ponto significaria aproximar-se dele, razão pela qual as noções tradicionais de viagem e de exotismo desapareceram. $\mathrm{O}$ mundo teria se aberto, então, para a circulação orbital, modo de se deslocar no qual o turista passa a ocupar a figura do viajantedescobridor. Com a decadência das narrativas de viagem e do gênero de aventura, considerando a perspectiva de Segalen, a solução criativa para a renovação do gênero foi explorar o tema das jornadas extraplanetárias, isto é, as viagens galácticas e intergalácticas.

Obviamente, a histórica experiência colonizadora também foi responsável por guiar a imaginação humana nessa nova seara da aventura. A viagem de turismo, de cerne consumista, também foi tematizada; contudo, tal forma de viajar é possível apenas após a instituição das condições materiais que vão da descoberta, colonização, mapeamento, construção e iconização dos territórios. Alguns títulos cinematográficos podem ser citados para ilustrar tais questões. Em Planeta Proibido (Forbidden Planet, Fred M. Wilcox, 1956), o narrador explica que depois da conquista da Lua, o primeiro destino exótico extraplanetário, o ser humano chegou a outros planetas do Sistema Solar e, com novas descobertas científicas, foi possível empreender o domínio e a colonização do espaço. Da mesma forma que ocorreram as políticas europeias de incentivo à colonização do Novo Mundo, nas campanhas publicitárias corporativas de Blade Runner - o caçador de androides (Blade Runner, Ridley Scott, 1982), as colônias extraterrestres representam o lugar para começar uma nova vida, em um paraíso pós-moderno repleto de novidades, discurso que caracterizaria um 
novo estágio do neocolonialismo - contraparte moderna e tecnológica do colonialismo empreendido pelas nações do Velho Mundo. Já a história de O vingador do futuro (Total Recall, Paul Verhoeven, 1990), amparada na ideia de viagem de turismo, apresenta como gatilho narrativo um personagem desejoso de visitar lugares icônicos do planeta Marte, tendo como único impeditivo os altos custos dos cruzeiros espaciais.

No contexto da colonização, a ficção alienígena possui como tendência produzir alegorias políticas como expressão do poder (ideológico, tecnológico, bélico, epistemológico, corporativo). Logo, o que se pretende aqui é demonstrar de que modo tal hipótese está refletida na iconografia do gênero e em eventos narrativos muito característicos. Os filmes da década de 1950 e 1960, por exemplo, têm uma relação muito evidente com o Colonialismo, as Grandes Guerras e a Guerra Fria; para o espectador contemporâneo, são mais reveladoras as imagens metaforizadas dos imigrantes econômicos, do apartheid racial, do exílio político, do fundamentalismo nacionalista ou religioso, do terrorismo. Não interessam neste ensaio questões relacionadas aos efeitos emocionais das histórias analisadas, como deveria inspirar o estudo da monstruosidade alienígena no gênero de horror, sendo privilegiado o mapeamento de uma narrativa trivial, de matriz política, não se distinguindo os valores críticos ou de produção do corpus, de modo que produções B, blockbusters, produções para TV ou vídeo, filmes reconhecidos pela crítica recebem a mesma atenção teórica.

Essa narrativa trivial da ficção alienígena seria uma forma profundamente marcada pela experiência histórica do imperialismo e sua retórica do poder. Com algumas exceções, a figura do alien é representada como símbolo da negatividade e, se não rivaliza, representa o lado negro do próprio homem. Os seres do espaço não parecem ser tão mais temidos quanto o foram ou ainda são os estrategistas de regimes totalitários, os imperialistas desbravadores ou, mais recentemente, os administradores de conglomerados multinacionais. O mito alienígena global e interplanetário deve ser encarado como símbolo de uma crise planetária.

\section{IMPERIALISMO, (NEO)COLONIALISMO E FICÇÃO ALIENÍGENA}

O significado original da palavra latina alienígena designa todo aquele que é natural de outro país, um estrangeiro ou forasteiro. Foi em virtude do frequente uso figurado no cinema e na literatura que se tornou uma expressão popularmente conhecida para designar seres de outros planetas. A gênese da ficção alienígena, como narrativa de alteridade da própria história humana, é um misto de histórias e lendas, comportamentos sociais e determinantes psíquicas que funcionam, na maioria das vezes, como alegoria ou sátira política e social.

Além da identificação íntima com a noção de estrangeiro, o alien é alegoria da condição humana por enfocar a bestialização do ser pelo caminho da ciência, da tecnologia e da política, isto é, a criação de monstros morais. Segundo essa leitura, deve-se compreender, ainda, sua diferenciação do resto dos seres humanos não como um lugar de origem e, sim, como um lugar de poder. O centro de um poder ditatorial seria o lugar privilegiado para que um forte instinto primitivo e animal fossem desenvolvidos, mesmo que balizado por um enorme apelo à razão. A uma razão bastante questionável, digase de passagem. A moralidade, no sentido da preservação da espécie, é sempre o limite da razão.

É bastante significativo que no universo ficcional de A Guerra dos Monstros (Godzilla vs. Monster Zero/Kaijû daisensô, Ishirô Honda, 1965), construa-se a fábula da união internacional por meio da Autoridade Espacial Mundial, contexto no qual não há governos dominantes, o que contraria a versão hollywoodiana de que os EUA são a (única) patrulha (possível) do Universo. No roteiro, uma viagem espacial promovida pela AEM, tripulada por um astronauta japonês e outro americano, parte para o recém-descoberto Planeta $\mathrm{X}$, situado atrás de Júpiter, depois de detectadas interferências de rádio originadas desse lugar. A união nipo-americana parece uma forma simbólica - mas não suficiente e nem possível - de corrigir atos históricos passados, especialmente pela cena na qual um dos viajantes hasteia uma bandeira tripla em solo extraterreno: a do Japão, dos Estados Unidos e da ONU. O gesto, por si só, já representa uma atitude territorialista bastante comum, como a que aconteceu com os astronautas americanos na conquista à Lua em 1969, durante a corrida espacial entre EUA e URSS, ou mesmo, na forma primitiva da cruz levantada em território brasileiro por conquistadores portugueses durante a época das Grandes Navegações.

A versão em português do título, A Guerra dos Monstros, parece reportar tanto à ideia de monstro moral representando por governos imperialistas, quanto aos monstros reais - Godzilla, Rodan e King Ghidorah - que os habitantes do Planeta X pretendem empregar para dominar a Terra. A princípio, a única saída para a catástrofe fantástica seria o uso de todo armamento nuclear disponível, solução que desagrada a todos, de modo que os obriga a encontrar um meio mais simples e eficaz de contenção um aparelho de ondas eletromagnéticas, responsável por controlar as criaturas. Como se pode notar, o trauma moral provocado por conta dos armamentos nucleares, como em Hiroshima e Nagazaki, impede até mesmo o uso positivo da energia atômica, ao menos neste audiovisual de produção japonesa.

O que importa ressaltar é que as narrativas alienígenas pretendem situar o lado mal da própria história humana em fictícias civilizações espaciais, sem, no entanto, deixar de expressar, ainda que sub-repticiamente, questões de soberania política de certas 
nações terrestres sobre outras. Afinal, as histórias de encontro de civilizações, na grande maioria das vezes, se dão a partir de um viés bélico.

Apesar de semelhantes representações de supremacia, uma das fantasias humanas veiculada por narrativas alienígenas (e, de forma mais moralista, nos filmes-catástrofes) é a do "sonho da indiferença”, isto é, o desejo de unidade planetária que possa acontecer por conta de uma emergência internacional e perpetuarse depois dela, indiferença como acontecimento de não discriminação de ordens sociais complexas (raça, credo, nação etc.). Em Viagem ao sétimo planeta (Journey to the seventh planet, Sidney W. Pink, 1962), o narrador do filme nos informa que uma característica peculiar da raça humana é tornar realidade suas visões. O bem maior que se deve sublinhar, no entanto, não é a ênfase na conquista paulatina do tempo e do espaço, por meio das viagens espaciais; é, sim, descobrir que, no ano de 2001, de acordo com o roteiro, nosso planeta seria governado pela Organização das Nações Unidas, não se encontrando mais dividido, em estado de guerra ou sob a ameaça de alguma aniquilação em massa. O ser humano viveria em harmonia com o próximo, apenas em busca de sabedoria e do bem-estar da humanidade, visando o todo e não apenas o particular. Visão semelhante ao bíblico Éden e, também, à utopia do Bem Comum. O narrador trata de uma fantasia baseada na noção cristã de Paraíso terrestre ou na utopia da República ideal, condições de existência que nada tem a ver com a realidade política - nem a mais distante. Em Planeta Proibido (Forbidden Planet, Fred M. Wilcox, 1956), há algo semelhante - a Organização dos Planetas Unidos -, surgida depois que a humanidade empreendeu a conquista e a colonização do espaço sideral.

A despeito dos sonhos da indiferença, em contextos ficcionais ou históricos, políticas autoritárias e predatórias operam em uma ditadura do invisível. E o poderio, no qual se sustentam muitos governos ainda hoje, definitivamente encena a presença exploratória alienígena. Em O Predador (Predator, John McTiernan, 1987), o exército norte-americano, em missão por uma selva da América Central para resgatar uns soldados e um ministro da Guatemala de guerrilheiros, depara-se com um alienígena destruidor. No filme Frankenstein contra o monstro do espaço (Frankenstein Meets the Spacemonster, Robert Gaffney, 1965), é somente a força militar norte-americana que tem capacidade para conter os captores aliens aterrados em Porto Rico, um território não incorporado dos Estados Unidos e sobre o qual têm influência direta.

Qual conteúdo ideológico poderia estar implícito nessas "inocentes" narrativas? Como afetam as questões de soberania e identidade de cada teto político? O que pertence aos Estados subdesenvolvidos ou em desenvolvimento, principalmente no âmbito dos bens naturais, precisa ser controlado por uma administração exógena e segundo leis internacionais, como acontece na polêmica em torno da possível desbrasileirização da Amazônia? O exótico e o "intocado" representam perigo ou fonte de renda aos países do Primeiro Mundo? Afinal, olhando para trás, em matéria de recursos naturais, determinadas superpotências mundiais se comportaram como protetores ou predadores do planeta? Que discursos podem ser utilizados para a apropriação das riquezas naturais do globo? Qual o papel do tema da segurança pública em relação à prática política?

E o que dizer do caso das relações econômicas perpetradas por empresas multinacionais e transnacionais espalhadas pelo globo, sobretudo em países empobrecidos e submetidos por uma dominação econômica, à parte do domínio político estatal? Na senda das apologias alienígenas para o medo de invasões bárbaras, ocupações geográficas, disputas por recursos minerais e poderio econômico, é preciso citar um dos piores conflitos do Oriente Médio, a Guerra do Golfo, ocorrida em 1991, envolvendo Iraque e Kuwait. No quesito da representação da invasão territorial, Saddam Hussein, tal como foi divulgado pela mídia ocidental, chega bem perto da figuração de um imperialista predador. Creditando ao Kuwait a responsabilidade pela queda no preço do petróleo, o ditador iraquiano, depois de invadir o país vizinho, chegou a considerar o Kuwait uma província do seu Estado. Esse problema político-econômico que, ao final, acabou reavivando antigas disputas geográficas na região e atraindo a atenção de outros países. $\mathrm{Na}$ época, liderados pelo governo de George H. W. Bush, os norteamericanos intervieram na disputa, lutando ao lado do Kuwait, a fim de libertar os poços petrolíferos das mãos dos iraquianos. $\mathrm{O}$ resultado, como se sabe, seria a continuação das rivalidades durante a Guerra do Iraque, cujo motivo principal era garantir a exploração do petróleo por empresas yankees. Nesse sentido, soa familiar a cegueira alienígena pelo controle mundial e apropriação dos bens naturais.

Cabe lembrar, também, que, depois dos atentados de 11 de setembro de 2001, os Estados Unidos, sob a presidência de George W. Bush, lideraram uma política anti-iraquiana, acusando este governo de ser uma grave ameaça à segurança de outras nações e à ordem mundial. A inspeção do Conselho de Segurança da ONU comprovou, mais tarde, a impossibilidade do Iraque produzir qualquer tipo de arma nuclear, desmentindo as provas apresentadas por Colin Powell, Secretário de Estado norte-americano, e aceitas por Tony Blair, Primeiro-Ministro da Inglaterra. Mas, mesmo sem o respaldo do órgão internacional, os exércitos dos EUA e do Reino Unido iniciariam um conflito armado com o Iraque em 2003, finalizado só em 2010. Os americanos foram enormemente criticados em sua posição de invasores, sobretudo em razão do número desnecessário de baixas civis iraquianas e da pilhagem praticada pelas forças de ocupação contra propriedades públicas e privadas, sobretudo na forma da agressão simbólica aos artefatos culturais e históricos do país. Pensadores como Jean Baudrillard e Edgar Morin (2004) haviam qualificado o atentado de 11 de setembro como uma destruição simbólica, que é superior à destruição física - ao desabamento arquitetônico e ao número de mortos. E justamente esse sentido mais profundo de agressão teria levado o país ofendido, os EUA, ao conflito armado, movimento 
comparável à revolta bélica da Alemanha em resposta às reparações impostas pelo Tratado de Versalhes em 1919.

Embora para muitos possa parecer um clichê visual, a destruição de pontos turísticos (Torre Eiffel, Estátua da Liberdade, Big Ben, Cristo Redentor etc.) e de centros de poder (Casa Branca, Casa Rosada, Palácio de Buckingham etc.) possui razões precisas para estar em boa parte das narrativas alienígenas: a) os símbolos são estruturas amplamente conhecidas pelo público, o que permite o pronto reconhecimento das diversas partes do mundo atacadas; b) os símbolos, sob uma ótica da identidade cultural, são imagens materializadas da nacionalidade e da nação. Em Guerra dos Mundos (War of the worlds, Byron Haskin, 1953), a título de ilustração, é mostrada a queda da Torre Eiffel, a invasão da baía da Guanabara e a destruição do Taj Mahal. O ataque aos símbolos nacionais, portanto, é uma espécie de afronta à moral dessas nações, sublinhada pelo aniquilamento dos polos de controle central do Estado, um modo de apresentar metaforicamente o caos e a desarticulação governamental. Portanto, colocar abaixo uma referência visual comum, na verdade, funciona como metonímia para demonstrar a nós mesmos a fragilidade militar do país frente à ocupação de forças militares cósmicas.

A noção de identidade nacional tem sido diluída ou relativizada radicalmente nos últimos tempos em função do aprofundamento dos processos de globalização e mundialização culturais. Pode-se dizer que, em certo sentido, as grandes metrópoles se assemelham em seu cosmopolitismo, parecendo constituir um idêntico espaço transnacional. Segundo essa ótica, invadir a Terra-nação, sem distinguir governos locais, ainda que as narrativas nos mostrem a argúcia da desarticulação dos centros urbanos pelos invasores, é um modo de tratar a oposição alienígena em termos globais: a identidade planetária versus a identidade forasteira. Em última análise, pode-se dizer que o embate entre as civilizações apenas se dá frente a um exotismo radical, razão pela qual a fantasia da unidade internacional poderia ser produzida mais resolutamente nos dias de hoje, isto é, a imaginação cinematográfica torna muito verossímil a supressão das diferenças (apesar das forças de pasteurização presentes no mundo ocidental) humanas (raça, etnia, credo, política etc.) em caso de luta armada por um bem comum - o planeta Terra.

Em casos de invasão alienígena e destruição global, há o abandono temporário, ainda que à revelia, da manutenção da diferença de culturas e de identidade locais - ou, em outros termos, nacionais e nacionalistas - em prol do reforço de uma visão mais homogênea, a de humanidade, para que possa se dar o enfrentamento com uma alteridade radical, a raça alienígena. Contudo, como o volume majoritário de produções científicas dessa natureza é norteamericano, ocorre frequentemente uma identidade entre os heróis humanos vencedores e a sua procedência da Águia Americana, como provavelmente seria o movimento natural em qualquer outro país de origem da produção. O herói ser nativo de uma nação, portanto, não constitui um problema em si em meio a essa temporária, hipotética e utópica dissolução das diferenças - a verdadeira questão é verificar quais são os discursos subsistentes dos representantes dessas nações em relação às outras, por exemplo, e como as ideias de soberania parecem manter-se intactas a despeito de tudo. Esses fatores podem evidenciar que a suspensão dos preconceitos de identidade é apenas parcial, uma vez que, como proposto pela metáfora do iceberg, as tensões são mantidas ocultas e latentes, fora de uma visão de superfície.

A destruição dos centros de poder e dos ícones culturais de uma nação, nesse sentido, também colabora para expressar concretamente a impotência dos governos nacionais, mesmo o das grandes potências, pois é uma ferida no centro nevrálgico de uma dada soberania política e territorial, metáfora que expressa o aniquilamento da imponência e revela uma condição de inferioridade. Por isso, qualquer forma de invasão é bastante delicada. Em Independence Day (Independence Day, Roland Emmerich, 1996), uma raça alienígena invade o planeta destruindo as principais cidades do mundo. Inúmeros símbolos da democracia, como a Casa Branca e até a vizinha Casa Rosada, simplesmente explodem pelos ares. Mas o governo norte-americano, como sempre, aliado e, de algum modo, à frente das outras nações, derrota os inimigos e o faz justamente no dia em que comemoram sua independência. É de se pensar muito a implicações de sentido do contexto narrativo. Quando afirma que, a partir daquele dia, o Independence Day seria lembrado não apenas por norteamericanos, mas pelo mundo todo, o filme reafirma implicitamente uma mensagem de supremacia dos EUA, não apenas mundial, mas também intergaláctica. São representações de poder inoculadas sobre o espectador menos crítico ao modo de uma disfarçada propaganda política, especialmente em semelhantes reafirmações do poderio econômico político e militar de algumas potências internacionais sobre o futuro do mundo. Tudo porque a hibridação de gêneros, como os de ação e ficção científica, colabora para que subtextos alegóricos venham disfarçados na forma de puro entretenimento.

No remake de O vingador do futuro (Total Recall, Len Wiseman, 2012), construído segundo as fórmulas de um gênero misto entre thriller e sci-fi, muitas questões políticas são apresentadas aos espectadores. No futuro previsto pelo roteiro, em fins do século XXI, a humanidade teria sofrido as terríveis consequências de uma guerra química, o que tornou praticamente grande parte do território mundial inabitado - estado final que repercute os temores da aniquilação em massa pós-Hiroshima e o de ataques bioterroristas pós-11 de setembro. Em resumo, os dois territórios habitáveis que restaram - A União Federativa da Grã-Bretanha e a Colônia (antiga Austrália) - mantém fortes relações de poder do primeiro sobre o segundo, expressando os mesmos excessos da Metrópole e a subserviência das colônias ao longo (e muito depois) do século XV. O símbolo da opressão político-econômica desse universo é "A queda" (The fall), o único meio de transporte a conectar os dois territórios e que também funciona ao modo de uma barreira de controle alfandegário e de imigração. 
No tempo diegético da história, como os espaços habitáveis tornaram-se o artigo de luxo, conquistar os espaços disponíveis torna-se uma necessidade imperativa, razão pela qual o chanceler da União cria midiaticamente um inimigo do Estado a fim de justificar a captura deste falso líder terrorista, interromper qualquer ajuda humanitária ao governo colonial - acusado de coalisão com a militância terrorista - e, ainda, empreender uma invasão total à colônia. Por esse viés é factível estabelecer semelhanças com as políticas de George W. Bush e a invenção do inimigo do Ocidente, Osama bin Laden, como justificativa para a invasão e o conflito militar no Afeganistão e no Paquistão. Ou, passando da história à literatura, até mesmo recordar o temido Emmanuel Goldstein, inimigo ficcional do Estado, governado pelo Grande Irmão no romance 1984, de George Orwell.

Seja como for, o remake de $O$ vingador do futuro, contrariando a adaptação cinematográfica de 1990, não apresenta colônias marcianas, de modo que estabelece o foco dos conflitos coloniais em nosso próprio planeta, o que estimula a reflexão sobre um possível futuro sombrio para a humanidade - resultado de uma conjuntura de medidas não sustentáveis de desenvolvimento, aumento do crescimento da população, aprofundamento da diferença de distribuição de riquezas, ascensão de novos governos totalitários, etc. O que está em questão na fábula do diretor Len Wiseman é a luta pela independência, isto é, da transformação de um centro colonial em um país independente por meio de uma revolução (empreendida pelo "patriotismo" da Resistência em relação à União). Nesse sentido, a destruição do símbolo arquitetônico que representa a separação e o jugo autoritário, parece remeter ao mesmo significado de um evento histórico, que, embora não trate $a$ priori do processo de independência, expressa o fim da segregação de sistemas políticos e econômicos - o socialismo e o capitalismo na Alemanha e no mundo. "A queda", o meio de transporte destruído, transforma-se facilmente no Muro de separação de um teto político que se quer distinto, o movimento inverso da Queda do Muro de Berlim em 1989, o de reunificação, acontecimento que, para alguns historiadores, marca o fim da Guerra Fria e das utopias políticas. A destruição do símbolo do poder da União Federativa é uma destruição simbólica do poder encarnado por ele (seria intencional a semelhança física com as Torres Gêmeas?); seu esfacelamento, não sem razão, ocorre durante o assassinato do chanceler e a derrota do seu exército da Polícia Federal Artificial, agentes androides com ordem para considerar qualquer cidadão da colônia hostil, empregar força letal se preciso e para operar a invasão "necessária e ostensiva" ao território colonial.

Com base em exemplos - tanto da ficção quanto da história -, compreende-se ser público e notório que muitos governos não agem por princípios altruístas, visto que querem defender tão somente os próprios interesses. Lutar a favor de alguma nação (ou de todas elas) ou governo significa estabelecer um dever moral que, cedo ou tarde, pode significar uma troca de bens. Se considerado que muitos extraterrestres, de acordo com as fábulas alienígenas, vêm ao planeta Terra por conta do esgotamento de seus recursos naturais, o nosso sistema econômico planetário é facilmente equiparável ao deles.

As nações parecem estar criando uma rede de futuros "parceiros" para quando seus próprios recursos estiverem chegando ao fim, e não somente aqui, no espaço também. Por que será que sondas espaciais andam a procura de vida em outros planetas e, principalmente, em busca de um lugar com condições climáticas semelhantes às do nosso? Por que virou manchete em jornais e revistas do mundo a descoberta de planetas como o Gliese 581c? Não estariam os cientistas procurando uma possível saída para o futuro autodestrutivo do homem, tal qual acontece nas fábulas alienígenas? Os relatórios a respeito das condições do clima para o futuro não parecem favorecer muito a condição de vida na Terra, fato confirmado pela obstinação em procurar mundos como esse tal Gliese 581c, designado por cientistas como a "segunda Terra". Pelo menos no imaginário cinematográfico, como acontece em Battleship - A batalha dos mares (Battleship, Peter Berg, 2012), o sistema solar de Gliese já foi contatado e a alien response veio na forma de um hostil confronto bélico entre mundos, provavelmente com desejos de ocupação do que seria também para eles um segundo planeta.

Ou seja: os filmes tratam do ser humano sendo colonizado por alienígenas, quando, a essa altura da história, é o próprio ser humano que quer assumir esse papel no universo. E se o cinema foi um precursor na abordagem de temas em que o ser humano faz de outros planetas suas colônias, o que simbolizam iniciativas como o Projeto Biosfera II? Desenvolvido a partir de 1991 como um simulacro do espaço terrestre, a experiência norte-americana fracassou depois de reproduzir artificialmente um microcosmo de sete ecossistemas isolado por uma estrutura de ferro e vidro no Arizona - primeira tentativa de criar um modelo arquitetônico de colonização do espaço extraterreno. O insucesso da experiência contribuiu para manter o sonhado processo de terraformação apenas na teoria; ou praticável apenas na ficção.

Passando das telas do cinema para os telejornais, não foi propriamente a luta pela soberania o que se viu após a destruição das Torres Gêmeas, no fatídico 11 de setembro. Depois do incidente, o governo de George W. Bush iniciou uma caçada aos "alienígenas" do terrorismo e o Oriente Médio (mais parte da Ásia e África) se tornou, novamente, o espaço sideral de onde derivavam as forças hostis a atacar a Humanidade. A Guerra ao Terror teve a intenção de se espraiar mundialmente, e muitos governos involucraram-se no tema, assumindo o que havia acontecido nos EUA, como uma ameaça ao mundo inteiro (mesmo que isso, realmente, fosse somente sua porção "Ocidental"). Nesse embate entre Ocidente e Oriente, frequentemente o primeiro trata o segundo como uma raça inferior, reducionismo denunciado por Ian Buruma e Avishai Margalit (2006). Esses teóricos, contudo, não se ocupam de tão somente vitimizar o povos orientais, pois também afirmam que o preconceito ocidentalista - redutor da civilização ocidental a "uma massa de parasitas sem alma, decadentes, ambiciosos, desenraizados, descrentes e insensíveis" - é tão 
simplista e destrutivo quanto o do olhar orientalista. Logo, a outridade parece ser sempre um inimigo.

Quanto às invenções dos inimigos, é salutar recordar as oposições entre os regimes político-econômicos durante a Guerra Fria, tema persistente nas ficções de temáticas alienígenas. O filme Vampiros de almas (Invasion of the Body Snatchers, Don Siegel, 1956) ${ }^{3}$ é um ilustrativo representante das oposições de cerne político. A fábula gira em torno de um médico lidando com um tipo de histeria epidêmica em massa, ou de paranoia conspiratória, por meio da qual as pessoas acreditavam que os seus entes mais queridos estariam sendo substituídos por cópias alienígenas. Na diegese, sementes cósmicas, formadoras de uma vagem-casulo, reproduziam os corpos humanos e destruíam os originais quando terminado o processo, perfazendo uma silenciosa invasão. O tema do familiar/estranho - o umheimlich freudiano - sutilmente remete ao período da Guerra Fria ${ }^{4}$, especialmente quanto ao temor de agentes duplos (americanos/soviéticos) infiltrarem-se em diversos setores do país. A perseguição política de Joseph McCarthy, o Macarthismo, ocorrida entre as décadas de 1940 e 1950, muito colaborou para uma desconfiança generalizada da população, impulsionando todos e cada um a uma caça aos comunistas. No filme, embora os alienígenas possuam a mesma aparência física e as lembranças do corpo humano duplicado, eles demonstram comportamento frio, sem emoção, inumano, o que também parece remeter às invencionices sobre comunistas, como a de serem comedores de criancinhas.

Em Vampiros de almas, além do mais, há uma mensagem sutil sobre a alienação, sobretudo porque os alienígenas defendem que viver seria mais simples sem a complexidade das emoções, isto é, realizar atividades tão só por instinto de sobrevivência. Emocionalmente analfabetos também são os alienígenas de Casei-me com um monstro do outro espaço (I married a monster from outer space, Gene Fowler Jr, 1958) $)^{5}$, originais de um planeta destruído e condenados à extinção por terem restado apenas espécimes machos. A intenção deles, então, é tomar o planeta pela fecundação de nossas mulheres, geração de descendência ou de herança que pode ser metáfora para a disseminação ideológica do comunismo. Assim, a paternidade dos forasteiros e sua presença repulsiva entre nós (especialmente na América do Norte), corresponderiam, portanto, ao perigo de um estranho conjunto de convicções políticas. O Macarthismo, em certo sentido, parece ter transformado uma conhecida expressão da ficção científica ao substituir o sujeito original por outro: "os comunistas estão chegando”. Em Guerra dos Mundos, na versão de Byron Haskin, além de uma referência à energia atômica - em

${ }^{3} \mathrm{O}$ filme é baseado no romance The Body Snatchers, do americano Jack Finney, publicado em 1955. Outras três adaptações cinematográficas surgiram: Os invasores de corpos (Invasion of the Body Snatchers, Philip Kaufman, 1978); Os invasores de corpos - a invasão continua (Body Snatchers, Abel Ferrara, 1993); e Invasores (The Invasion, Oliver Hirschbiegel, 2007). A versão de Siegel passa-se na pequena e ficcional cidade de Santa Mira, Califórnia; a de Kaufman, em São Francisco, Califórnia; a de Hirschbiegel em Washington.

${ }^{4}$ Em uma das falas do psiquiatra Dr. Danny Kauffman, fica clara a referência ao comunismo, pois, em sua avaliação, a histeria coletiva seria uma resposta ao que estava acontecendo no resto do mundo, ou seja, a Guerra Fria. termos de um embate nuclear - devido à radioatividade dos objetos vermelhos, desenhados em formato de cisnes ao invés dos trípodes de H. G. Wells, há um forte indicativo simbólico do sistema político dos rivais dos americanos, ainda mais porque os invasores vêm de um planeta de "cor comunista".

Outro filme que parece ter embarcado na mesma alegoria política é A bolha assassina (The blob, 1958, Irvin S. Yeaworth Jr. e Russell S. Doughten Jr.), ao tratar da queda de um meteorito em território americano e cuja gosma vermelha do seu interior vai crescendo de tamanho à medida que devora suas vítimas. A cor do ser amorfo parece uma referência óbvia ao comunismo. Além desta informação visual, um dos personagens, um policial, expressa um trauma concentrado em relação à guerra e os dias de hoje, paranoia que se amplia de modo generalizado durante a Guerra Fria. Por fim, a conclusão dos captores da bolha é que aquilo não pode ser destruído, somente contido (no caso, congelado com CO2) -, possivelmente da mesma forma que uma ideologia não pode ser exterminada, apenas refreada.

No remake de A bolha assassina (The blob, Chuck Russell, 1988), o meteoro que atingiu a pequena cidade tratava-se, na verdade, de um satélite do governo norte-americano. Este continha um vírus experimental - algo para uma futura guerra biológica - que acabou por transformar-se em uma forma de vida plásmica e predadora. $\mathrm{O}$ embate velado entre americanos e russos se mantém. Mas, como aquele germe monstruoso poderia afetar o equilíbrio do poder mundial se descoberto pelo público antecipadamente, a população da cidade havia sido considerada sacrificável - tema da insensibilidade governamental que os coloca em pé de igualdade com a crueldade de invasores alienígenas. Por sorte, a mesma solução - a do congelamento - foi descoberta, mas um reverendo guarda uma amostra da bolha para criar um tipo de igreja apocalíptica, na qual o monstro devorador seria utilizado como um instrumento de "deus".

A sequência da produção de Stanley Kubrick, 2010 - o ano em que faremos contato (2010 - The year we make contact, Peter Hyams, 1984), apresenta um universo futurista em relação à época, o anotítulo da obra, em que americanos e russos ainda manteriam os mesmos conflitos de forças da Guerra Fria. O drama paralelo ao da tripulação russo-americana em busca do monólito de Júpiter são os graves problemas políticos na América Central, especialmente em Honduras, e do bloqueio imputado a este país pelos Estados Unidos - razão pela qual a equipe de astronautas acabe por colocar mesquinhas questões políticas acima da colaboração científica. Por

\footnotetext{
${ }^{5}$ Neste filme também há uma duplicação dos corpos humanos para a ocupação alienígena sem, no entanto, implicar na destruição dos originais. E, da mesma forma que Vampiros de Almas, a pequena cidade invadida tem a comunicação com o exterior interrompida/controlada - telegramas e telefonemas - e a saída de pessoas controlada pelas autoridades. Os rumores sobre a presença de alienígenas na cidade também são considerados histeria coletiva.
} 
fim, expressando uma ingênua mensagem moralista, os viajantes do espaço e os terráqueos estabelecem contato com uma das luas de Júpiter, Europa, e recebem a seguinte mensagem de paz: "Todos esses mundos são seus, exceto Europa, não tentem entrar lá. Usemno juntos, usem-no em paz". Tão logo ocorre a transmissão, Júpiter transforma-se em um segundo sol do Sistema Solar, fenômeno que levou militares americanos e russos a recolher seus armamentos e cessar o conflito. Este acontecimento astrológico sem precedentes pareceu realinhar as relações daquele fictício ano de 2010, especialmente porque finalmente os seres humanos descobriram que são apenas "inquilinos neste mundo" ao receberem um "novo contrato e um aviso do proprietário", algo semelhante à mensagem dada por Deus a Adão e Eva no Jardim do Éden (e para fora dele).

Na pior das hipóteses, ao contrário dos proprietários - os vigilantes do monólito negro -, haveria a figura do stalker alien da abertura do remake de Guerra dos mundos (War of the worlds, Steven Spielberg, 2005):

Ninguém acreditaria, nos primeiros anos do século 21, que o nosso mundo era observado por seres mais inteligentes. Que enquanto os homens se ocupavam de suas várias atividades, eles eram observados e estudados da mesma forma que o homem, com um microscópio, analisa as criaturas que se multiplicam em uma gota d'água. Com infinita complacência, os homens exerceram suas funções confiantes no nosso domínio sobre este mundo. Enquanto, em outro lugar do espaço intelectos complexos, impassíveis e impiedosos, olhavam para o nosso planeta com olhos cobiçosos.

Este remake, contudo, encerra a narrativa de um modo bastante questionável, legitimando algo ilegitimável - o "genocídio natural" para o bem de todos:

Desde que os invasores chegaram, respiraram o nosso ar, comeram e beberam, foram condenados. Eles foram aniquilados, destruídos após todas as armas e equipamentos humanos falharem pela menor criatura que Deus, em Sua sabedoria, pôs na Terra. Pelo preço de um bilhão de mortes, $\mathrm{o}$ homem ganhou sua imunidade $\mathrm{e}$ o direito de sobreviver entre os infinitos organismos do planeta. $\mathrm{E}$ esse direito é nosso contra todos os desafios porque os homens não vivem nem morrem em vão.

Esse é um discurso muito próximo daquele que percebe e recalca as atrocidades cometidas por médicos nazistas nos campos de concentração, uma vez que muitas descobertas serviram ao bem geral da medicina.

Contudo, que dizer quando "a menor criatura de Deus" volta-se contra nós, varrendo um enorme número de vidas do mapa, corpos estranhos, corpos-aliens em nossos corpos? Certamente não é uma mensagem que se aplicaria a este caso. Invasores (The Invasion, Oliver Hirschbiegel, 2007), um dos remakes de Vampiros de almas, ainda sob o impacto do surto pandêmico do $\mathrm{H} 5 \mathrm{~N} 1$, o vírus da gripe aviária, ocorrido em 2005, apresenta uma fábula de invasão alienígena sem naves, raios lasers ou seres bestiais de outra galáxia.
A ênfase recai na ideia de uma pandemia provocada após a queda de um ônibus espacial contendo esporos de um vírus alienígena, responsável por destituir as pessoas de emoções e estabelecer um equilíbrio suprarracional. Um dos personagens, um embaixador russo, introduz a premissa da história, ao afirmar que um mundo sem violência, guerra e atrocidades seria um mundo inumano - e, a despeito da noção heroica de civilização pela qual somos guiados, ainda somos inteiramente movidos por instintos primitivos, bárbaros.

Os noticiários televisivos da ficção de Hirschbiegel cumprem um papel importante na história porque, enquanto os protagonistas precisam lidar com seus conflitos, a mídia faz a cobertura de conflitos armados em diversas partes do globo, como no Iraque, Teerã e China. Logo, um dos subtextos do audiovisual seria a alegoria da supressão da discordância; outro, a representação do medo do terrorismo, especialmente o biológico, e o das doenças infectocontagiosas. A invasão silenciosa poderia ser facilmente associada com o próprio contexto de infecção do $\mathrm{H} 5 \mathrm{~N} 1$ que, por sua vez, poderia nos remeter a outros momentos históricos, por exemplo, a chegada do brutal conquistador Hernán Cortés ao império asteca e, junto com ele, um aliado invisível e insuspeito, a varíola. E, não deixando de manter diálogo com a metáfora comunista da primeira versão, o roteirista faz o embaixador perguntar à psiquiatra Carol Bennell se ser russo é algo passível de cura e conclui: "Talvez ser russo neste país [os EUA] seja uma doença”. Contudo, ao contrário do primeiro filme, no qual a humanidade não tem escapatória, a nova versão mostra que os governos conseguem conter e imunizar a infecção viral, mas sem a garantia de proteção efetiva. Talvez, porque o remake tenha sido realizado depois da Guerra Fria, quando perigo comunista já não constituía uma ameaça como antes, cedendo lugar para outros perigos. A humanidade e a "alieniginidade", portanto, permanecem vulneráveis em ambos os lados.

Em Vênus ataca a Terra (Target Earth, Sherman A. Rose, 1954), a primeira reação da protagonista é temer um ataque aéreo de bomba-H a Chicago ou mesmo de uma guerra bacteriológica, o que bem expressa os temores do mundo na década de 1950 e, até mesmo, de tempos mais contemporâneos com o fantasma do bioterrorismo. Como se pode perceber, ao longo da história, as alegorias políticas acerca das narrativas alienígenas passaram a incluir outros temores, como o das epidemias e das ações terroristas. Em Guerra dos Mundos, versão de Spielberg, por exemplo, produzido em um contexto pós-11 de setembro, não é sem razão que um dos personagens se pergunte primeiramente se não estão diante de uma ação terrorista, como também acontece com os personagens de Cloverfield - monstro (Cloverfield, Matt Reeves, 2008) durante um ataque alienígena à cidade de Nova Iorque e no qual a cabeça da estátua da liberdade surge rolando pelas ruas em uma nuvem de poeira - eco provável das imagens de desabamento das Torres Gêmeas. 
O terror cósmico, em certo sentido, nutre-se constantemente do próprio "espaço sideral" de muitos binarismos (raciais, políticos, culturais), encontrando nos alienígenas a alteridade sem consequências de uma narrativa de entretenimento. Em Guerra dos Mundos e Cloverfield, os alienígenas estão claramente identificados com as etnias orientais, principalmente das regiões envolvidas na Guerra contra o Terror. Sempre há um Mal a ser combatido e, por consequência, um herói. A carga moralizante desses filmes está a serviço da doutrinação do que é bom ou ruim.

A disputa de poder das narrativas científicas em questão acaba por vezes mascarando a rivalidade entre aqueles que acreditam na supremacia de sua espécie: humana versus alienígena. O conteúdo preconceituoso de tal associação fica, então, patente. O segundo acredita seguramente em sua superioridade e, por isso, não pode conviver mutuamente com o ser humano em um mesmo planeta e vice-versa. Ora, o maior temor da humanidade quanto à presença de um ser alienígena é o de lidar com o desconhecido/alteridade, com uma entidade que não nos permita antever qualquer limite. Nessas condições, estar-se-ia diante do imensurável e do inominável, entre fronteiras que têm a ver com a capacidade para a dominação ainda que por meio da aniquilação. Essa contenda soa bastante familiar: permite que se lance luz sobre políticas preconceituosas de toda ordem, como antissemitismo de governos, como o nazista. A hegemonia da raça ariana difundida pelos ideólogos do Terceiro Reich deveria ser encarada como uma radical forma predatória alienígena.

Atrelado ao produto tecnológico, está o fato científico. Não são poucos os roteiros que tratam de surpreendentes histórias de abdução - o sequestro alienígena para fins de experimentação científica com humanos - bem ilustradas pela série televisiva Taken (Taken, Leslie Bohem, 2002) ou pelo terror da produção Contatos Imediatos do $4^{\circ}$ Grau (The Fourth Kind, 2008, Olatunde Osunsanmi). Na história da civilização, a abdução encontra uma prática semelhante de segregação, embora em escala numérica superior, reveladora do aspecto monstruoso contido no próprio ser humano, como convém relembrar acerca dos campos de concentração - os quais, diferentemente do que muitos supõem, foram sem dúvida potencializados na Alemanha pós-1940, mas cujo modelo precursor surgiu no fim do século XIX, nos EUA; e dos campos de refugiados - onde homens e mulheres ainda são abandonados a própria sorte, recebendo ajuda humanitária passageira, como ocorreu em Kosovo na última década do século XX e, sobretudo, em África e zonas de conflito no Oriente Médio.

Ao enfatizar a representação do alienígena como um estrangeiro com pretensões imperialistas e fortes discursos raciais e etnocêntricos, o filme Deu a louca nos nazis (Iron Sky, Timo Vuorensola, 2012) cria uma narrativa paródica e meta-histórica. $\mathrm{Na}$ trama, depois da derrota durante a Segunda Guerra Mundial, os alemães teriam se refugiado no lado oculto da Lua, ainda em 1945, construindo uma base militar em forma de suástica. O exército ariano atacaria a Terra 73 anos depois, em 2018, com naves-mães em formato de dirigível (referência ao conhecido Zeppelin) e outros discos voadores. Assim, imerso em anacronismos cômicos e baseado em um modo caricaturizado de apresentar o Reich lunar, somos levados a substituir o "os alienígenas estão chegando" pelo chiste "os nazistas estão chegando", substituição que pode soar ainda mais terrível, embora o contexto o utilize em seu sentido cômico. Dentre os inúmeros gracejos do filme, vale destacar o fato de que a professora na Lua Führer, inconsciente do que realmente significa o nazismo, crê ser O Grande ditador (The Great Dictator, 1940), curtametragem de Charles Chaplin, um filme laudatório das intenções "humanitárias" de Hitler. Além disso, a comicidade permite dessacralizar a ideia da unidade internacional representada pela ONU, especialmente em razão da ficcional presidente dos EUA estar mais interessada em estratégias de reeleição, constituindo, assim, a guerra uma ótima medida governamental, e dos representantes pertencentes à organização desejarem tão somente o melhor para suas próprias nações, mantendo projetos espaciais secretos à revelia do acordo internacional assinado, algo similar aos projetos de bombas atômicas e biológicas desenvolvidos secretamente pelos governos e em um contexto real.

Outra contraparte paródica da alegoria alien-estrangeiro está em Ataque ao prédio (Attack the block, Joe Cornish, 2011), no qual garotos de uma gangue de periferia precisam lidar a seu modo com invasores (nomeado por um dos personagens como aliens-gorilaslobos). Jogando com questões de imigração, violência urbana e narcotráfico da cidade de Londres, a narrativa estabelece como herói um jovem negro, significativamente chamado Moses (Moisés, em português). Ao final, de pequeno ladrão de subúrbio, transforma-se em um tipo de herói local e, embora tenha derrotado os monstros espaciais, não pôde escapar da punição da polícia. $\mathrm{O}$ menor dos crimes é tratado com o máximo de rigor, especialmente quando envolve estereótipos raciais dos seus perpetradores, o que reforça ainda mais o conteúdo preconceituoso e moralizante de tais filmes, especialmente ao insinuar qual o lugar correto de cada "coisa" no mundo.

A ideia dos párias da sociedade como possíveis salvadores também está presente em Invasão alien (The Salena incident, Dustin Rikert, 2007) ao retratar como condenados à pena de morte (um negro, um neonazista, um latino e um ítalo-americano) são obrigados a entrar em confronto com prisioneiros alienígenas sobreviventes da queda de uma nave-presídio. Além de marcar a teoria da conspiração de que outros mundos são conhecidos pelas instituições governamentais, mas mantidos eclipsados da opinião pública, joga minimamente com algumas questões éticas e raciais: o "skin-head" estava preso por arrastar pessoas presas à sua camionete e brincar de tiro ao alvo com elas, algo que remonta a outras crueldades cometidas ao longo da história; por fim e ironicamente, para salvar sua vida de um grave ferimento, este homem é obrigado a receber uma transfusão de sangue do prisioneiro negro. A mensagem, embora não apresentada de modo aprofundado, é de que o sangue é o mesmo para todos e a cor da pele, apenas um efeito de 
pigmentação; todas as raças são iguais, sobretudo quando sujeitos tão diferentes precisam lidar com catástrofes individuais e coletivas. Como narrativa ancilar do enfoque dado ao Outro está a figuração do exótico primitivo bem expresso pelo campeão de bilheteria Avatar (Avatar, James Cameron, 2009). O filme insiste em uma tese ingênua e maniqueísta: o ambicioso explorador oposto a uma bondade selvagem e harmônica em seu habitat natural - no caso, os exploradores são os terráqueos em busca de uma fonte de energia tão poderosa quanto lucrativa. Os alienígenas agigantados, de pele azul e em perfeita comunhão com seu mundo idílico, surgem então como os verdadeiros representantes da luta para salvar seu lar, cultura e mesmo raça, na figura arquetípica do bom selvagem atualizada ao contexto contemporâneo, no qual o homem deve buscar integrar-se à Natureza e não somente à civilização (cultura). A mensagem final ressalta, ainda assim, que, para nos vencer e expulsar, os nativos necessitam da ajuda de humanos de bom coração, capazes de liderá-los e ceder alguma tecnologia. Como os seres do planeta de três luas são desprovidos de armas nucleares e munição, o audiovisual sublinha que, até nos momentos em que somos maus, só perdemos para iguais. Nesse sentido, como enfatiza Susan Sontag (1987), os filmes de ficção científica evidenciam como o ser humano está nu sem seus artefatos. Sem a tecnologia - o símbolo do grau civilizatório -, ele não é nada, o ser humano se acovarda e aceita a derrota. E, no caso desse filme, a vitória é dos bons, e, em última instância, da sustentabilidade do planeta.

\section{CONSIDERAÇÕES FINAIS}

Este ensaio deu destaque, até o momento, aos indivíduos dizimados em nome da conservação de uma ilusória pureza de raça, representada por práticas anti-alienígenas de Hitler, Saddam Hussein, Mao Tsé-Tung ou Milosevic, mas convém recordar também que muitos o foram em função das terras e dos recursos que abrigam. Uma investigação do passado explorador da humanidade permitiria identificar quantos povos indígenas foram dizimados por exploradores portugueses, espanhóis, ingleses, franceses, belgas, italianos, etc. Aliens do Velho Mundo que queriam conquistar um território e explorar as riquezas naturais do local. Com certeza, para muitos tupiniquins, os portugueses foram seres monstruosos, vindos do "outro mundo" para ocupar, infectar e explorar, mesmo quando isso significasse destruir e dizimar. O discurso colonialista de outrora foi importado para as narrativas de ficção científica, como prova a fala de um analista no filme Invasão do Mundo: batalha de Los Angeles (Battle Los Angeles, Jonathan Liebesman, 2011) ao afirmar que a falta de comunicação ou de exigências dos alienígenas indicaria claramente a vontade de apropriação de recursos, o que implicaria a domesticação ou o extermínio da população nativa segundo a lógica da colonização. Ou o comentário

${ }^{6}$ Neste filme, o alienígena encontrado em Urano é um corpo em formato de cérebro e emite ondas (telepáticas?) para drenar as mentes dos astronautas terrestres e controlar seus desejos, especialmente por meio da projeção fantasmática de medos e vontades. A irônico de um cientista em Battleship - A batalha dos mares que, se caso alguma vida inteligente fosse descoberta em Gliese, seria "como Colombo com os índios, só que nós seríamos os índios”. Os invasores de A hora da escuridão (The darkest hour, Chris Gorak, 2011), em busca de metais que conduzam eletricidade - como o níquel e o cobre -, dizimaram a população terrena e instalaram torres de mineração ao redor do globo. A corrida espacial, em certo sentido, corresponde a uma corrida do ouro, tanto para terráqueos quanto para alienígenas.

Cowboys \& aliens (Cowboys \& Aliens, Jon Favreau, 2011), inspirado em graphic novel homônima, expressa o alienígena de duas formas: centrado na imagem do colono americano, invasor das terras indígenas durante a marcha para o (velho) oeste; e a do extraterrestre, função alegórica da alteridade, representativa dos perigos do estrangeiro em território conquistado. O filme, aliás, tematiza a luta de cowboys contra seres interplanetários mineradores de ouro e que, em vista da diferença de graus de civilização, querem apenas apropriar-se de recursos, dizimar a população local e sequestrar espécimes para estudos científicos dissecação, catalogação, experimentação. No roteiro da graphic novel, criada por Scott Mitchell Rosenberg (2011), o paralelo entre alienígenas/planeta Terra e conquistadores europeus/índios americanos é mais explícito, sendo enfatizado pelo prólogo do projeto gráfico. O texto ironiza as ações imperialistas e suas justificativas - "necessidade, compaixão ou providência divina" -, sobretudo o elemento mais perigoso do que uma tecnologia superior: o Direito Manifesto, a crença no direito e no dever dos americanos em dominar a barbárie indígena. Assim, ao passo que os americanos exigiam para si a posse do Arizona, no ano de 1873, por não constar em documentos de propriedade de ninguém (exceto na livre posse dos nativos), os alienígenas requeriam a conquista do planeta Terra, um "mundo virgem", não constante em nenhum mapa estelar da casta e, além disso, povoado por uma forma de vida primitiva (os seres humanos).

Esses exemplos demostram que a luta contra o "selvagem" ser extraterreno é uma versão atualizada das forças arcaicas dos mitos tribais ou dos empreendimentos dos heróis civilizadores, o que, em outras palavras, significa uma luta pela dominação da Natureza e seus componentes humanos em desenvolvimento (as nações indígenas ou indigenizadas aos olhos do invasor). Já em se tratando dos espécimes cerebrais de fábulas, como Os Invasores de Marte e Viagem ao sétimo planeta (Journey to the seventh planet, Sidney W. Pink, 1962) ${ }^{6}$, muitas vezes é expresso o medo de que os seres espaciais dominem nossa mente e nos submetam à vontade parasitária do invasor-conquistador. Ora, o discurso jesuítico da conversão, em tempos de poderio da Igreja Católica, criou uma correlação entre o discurso de salvação da alma e a prática de controle ideológico da mente. É um traço que podemos encontrar, inclusive, na carta de Pero Vaz de Caminha ao Rei D. Manuel I,

criatura, assim, pretendia atingir a submissão humana para a possessão alienígena completa, isto é, o controle da mente e a posse do corpo seriam o meio de conquistar Terra e destruir a raça humana. 
documento reconhecido como fundacional do nosso país, no qual a ideia de conquista está baseada em termos de posse e dominação de territórios, de riquezas e de almas. A aculturação de uma nação por outra é, nesse sentido, uma forma de parasitismo alien, de predatismo social e de prepotência invasora.

Tomar posse de terras/planetas cuja existência se tinha conhecimento, embora possa ser desconhecido o fato de serem ou não territórios ocupados, não justifica qualquer medida conquistadora de um sobre o outro, ainda que estejam em comparação dois modelos civilizatórios diferentes. Descobrir e conquistar, portanto, transformaram-se no discurso oficial de um jogo de poderes entre dois modelos civilizatórios (europeu e gentílico) existentes, que, ao se enfrentarem em termos de tecnologia bélica, cada qual defendendo sua soberania, criaram um processo extremamente violento e genocida, comparável aos horrores dos campos de concentração.

O período das Grandes Navegações, aliás, remete a uma época de contato dos habitantes do Velho Mundo, centro do Universo conhecido de então, não apenas com povos e territórios satélites (como a África e a Ásia), mas também com desconhecidos (a América e a Oceania). A disputa, a reorganização e, sobretudo, o desbravamento geográfico, político e econômico do globo se estenderiam pelos séculos seguintes, até atingir o ápice nas últimas décadas do século XX, quando, diante de uma tela do computador, não apenas autoridades governamentais de agências de inteligência detêm acesso a imagens de monitoração via satélite, mas a cada um de nós via web. A passagem de inexplorado para amplamente divulgado traria consequências. A morte da viagem e o início da circulação orbital - ou do turismo perpétuo, conforme sugerido por Jean Baudrillard (2004) - mostram que, em nosso mundo, não há mais o que descobrir, há apenas o que conhecer. O retorno da viagem, então, só pode se dar em termos interplanetários, fora da órbita da Terra, lugar para onde a ficção científica aponta.

Encarada desse modo, qualquer reverberação nas metáforas alienígenas não parece mera coincidência. Por isso, apesar do homem ainda não ter sido comprovadamente invadido por nenhuma raça alienígena, como na história de H. G. Wells, ao menos já prepara um imaginário invasor como autojustificativa para atos passados ou futuros; ou, pelo menos, cria um superego alienígena a fim de alertar e, de algum modo, reprimir nossos impulsos destrutivos, como se dá no clássico O Dia em que a Terra parou (The day the Earth stood still, Robert Wise, 1951). Esta ficção, aliás, na mesma senda de roteiros como os de A ilha da Terra (This Island Earth, 1955, Joseph M. Newman,), mostra que, apesar dos nossos defeitos, é possível apaixonar-se pela raça humana em razão do afeto e da expressão sensível, tal qual demonstram Klaatu ou Exeter. Pelo menos foi neste planeta que o Pequeno Príncipe descobriu o que é o amor e a responsabilidade afetiva, o Superman apaixonou-se e Jesus Cristo fincou sua filosofia baseada na caridade e amor ao próximo.
O paródico Palhaços Assassinos do Espaço Sideral (Killer Klowns From Outer Space, 1988, Stephen Chiodo, Eduard Chiodo e Charles Chiodo) parece concluir que a fábula da invasão alienígena é um espetáculo do tragicômico: chegando a uma pequena cidade a bordo de um circo voador, os invasores capturam homens em casulos de algodão doce, armados com pistolas de pipoca, teatro de marionetes, teatro de sombras, línguas-de-sogra, triciclos, balões, tortas ácidas. Ironicamente, o ponto fraco deles é o nariz vermelho. Nós, então, estaríamos de fato perdidos no mundo, indefesos como crianças, à mercê até mesmo de piadas grotescas do universo afora? Ou seria adentro?

Em Crônicas marcianas, de Ray Bradbury (2005), quase todos os nativos já haviam sido exterminados pela humanidade, e, depois que os homens foram embora para a Grande Guerra, o temido embate nuclear que varreu continentes do mapa, Marte tornou-se um planeta-túmulo. É, pois, assombroso o modo como terminam as crônicas de Bradbury, com uma pequena família exilada da Terra olhando para um reflexo na água e vendo-se como os novos marcianos. Os aliens, afinal, somos nós.

\section{REFERENCIAS}

BAUDRILLARD, Jean; MORIN, Edgar. A violência do mundo. Tradução de Leneide Duarte-Plon. Rio de Janeiro: Anima, 2004.

BAUDRILLARD, Jean. A transparência do mal: ensaio sobre os fenômenos extremos. Tradução de Estela dos Santos Abreu. Campinas: Papirus, 2004.

BRADBURY, Ray. As crônicas marcianas. Tradução de Ana Ban. São Paulo: Globo, 2005.

BURUMA, Ian; MARGALIT, Avishai. Ocidentalismo: o Ocidente aos olhos de seus inimigos. Tradução de Sérgio Lopes. Rio de Janeiro: Jorge Zahar, 2006.

LOVECRAFT, Howard Phillips. O horror sobrenatural em literatura. Tradução de Celso M. Pacionik. São Paulo: Iluminuras, 2008.

ROSENBERG, Scott Mitchell. Cowboys \& aliens. Tradução de André Gordirro. Rio de Janeiro: Galera Record, 2011.

SEGALEN, Victor. Ensayo Sobre el Exotismo: una Estética de lo Diverso y Textos Sobre Gauguin y Oceanía. Traducción de Jorge Ferreiro. México: Fondo de Cultura Económica, 1989.

SONTAG, Susan. A imaginação da catástrofe. In: Contra a interpretação. Tradução de Ana Maria Capovilla. Porto Alegre: L\&PM, 1987. p. 243-262. 